\title{
Vernacular Song and the Folkloric Imagination at the Fin de Siècle
}

\author{
ROSS COLE
}

In 1893 the polymath, folklorist, and eminent Jewish historian Joseph Jacobs read a paper-as a stopgap-to London's Folk-lore Society, which he had joined in 1889. Raised in Sydney, Jacobs journeyed to Britain in 1873; after graduating from the University of Cambridge, he studied briefly in Berlin and subsequently under Francis Galton. ${ }^{1}$ A prolific scholar with a seemingly boundless range of interests, Jacobs published literary essays, fought publicly against anti-Semitism, raised funds for the plight of persecuted Jews in Russia, and pursued demographic research to counter what he saw as the biological essentialism underpinning the question of race. Jacobs would later

\footnotetext{
I would like to thank Philip Bohlman, Nicholas Cook, Marina Frolova-Walker, Vic Gammon, Oskar Cox Jensen, and Ceri Owen. This project was funded by a grant from the UK Arts and Humanities Research Council.

${ }^{1}$ Anne J. Kershen, "Jacobs, Joseph (1854-1916)," Oxford Dictionary of National Biography (Oxford: Oxford University Press, 2004) (http://www.oxforddnb.com/view/article/ 51106, accessed 1 June 2016).
}

emigrate with his family to New York City, where he became Professor of English and Rhetoric at the Jewish Theological Seminary of America.

Simply titled "The Folk," the paper he delivered to the Folk-lore Society began as follows:

During the discussions which took place some years ago in the Folk-lore Society as to the nature of folk-lore, there was one curious omission. Much was said about what the Folk believed, what the Folk did, and how these sayings and doings of the Folk should be arranged and classified. But very little indeed was said as to what the Folk was that said and did these things, and nothing at all was said as to how they said and did them, and especially as to how they began to say and do them. In short, in dealing with Folk-lore, much was said of the Lore, almost nothing was said of the Folk. ${ }^{2}$

${ }^{2}$ Joseph Jacobs, "The Folk," Folklore 4/2 (1893): 233-38, 233. 
Reminding his audience that this "mysterious entity" presumed to be the folk was "many-minded," Jacobs states and restates a radical claim: "When we come to realise what we mean by saying a custom, a tale, a myth arose from the Folk, I fear we must come to the conclusion that the said Folk is a fraud, a delusion, a myth." ${ }^{3}$

Jacobs's polemic is striking not only for this audacious statement implicating the very concept of folklore as mythology, but also for his broader political commitment to understanding the complex patterns of human agency lying tacitly beneath folklorists' theories and collections. Stressing acts of individual artistry, initiative, and borrowing as points of origin rather than spontaneous acts of communal creation, Jacobs proposed that "the Folk is simply a name for our ignorance: we do not know to whom a proverb, a tale, a custom, a myth owes its origin, so we say it originated among the Folk" - wryly portrayed as "a publishing syndicate that exploits the productions of that voluminous author, Anon.." ${ }^{4}$ Furthermore, careful attention should be paid to the fact that communities are never entirely hermetic but rather in constant "culture-contact, mediate or immediate" with other locales, traditions, and ideas. ${ }^{5}$ One key consequence was that folklore could not be separated from the category of art: "We shall have to break down the rather hard and fast line we draw between folk-lore and literature . . . for, after all, we are the Folk as well as the rustic. ${ }^{16}$ Even more remarkably, yet another binary was to be leveled: "Breaking down the distinction between the Folk of the past and of the present, we shall be able to study the lore of the present with happy results. ... The music-hall, from this point of view, will have its charm for the folklorist, who will there find the Volkslieder of to-day." ${ }^{\prime 7}$

${ }^{3}$ Ibid., 234.

${ }^{4}$ Ibid., 235-36.

${ }^{5}$ Ibid., 236.

${ }^{6}$ Ibid., 237. On this point, see Adam Fox, Oral and Literate Culture in England, 1500-1700 (Oxford: Oxford University Press, 2000).

"Jacobs, "The Folk," 237. Such views of the music hall were extremely rare: see Ross Cole, "Notes on Troubling 'the Popular'," Popular Music 37/3 (2018): 392-414.
Jacobs's views have a strikingly modern character, yet they have not fared well in the century and a quarter that followed his paper. Throughout the intense disputes surrounding folk song over the years, such views-despite or perhaps due to their critical aptitude-have been silenced, drowned out, or simply forgotten. This article builds on Jacobs's ideas by foregrounding discrepancies between vernacular singing and the work of those affiliated with London's Folk-Song Society, founded in 1898. It offers a revisionist account critical not just of expropriative "mediation" but also of the conceptual framework motivating the very idea of folk song. ${ }^{8}$

The term Volkslied entered German historiography during the 1770 s courtesy of Johann Gottfried Herder, and cognate terms such as "national music" circulated during the Enlightenment. In Britain, however, influential ideas regarding folk song were institutionalized by figures with agendas and anxieties peculiar to the fin de siècle.' This era witnessed a series of jarring confrontations in which urban modernism clashed with Arcadian nostalgia, patriotic insularity with cosmopolitan internationalism, advances in technology and communications with reactionary impulses, and the apogee of Empire with bourgeoning socialism. ${ }^{10}$ By retracing the contours of the resulting discourse in relation

\footnotetext{
${ }^{8}$ A theory of mediation was advanced by Dave Harker in Fakesong: The Manufacture of British "Folksong": 1700 to the Present Day (Milton Keynes: Open University Press, 1985).

${ }^{9}$ See Philip V. Bohlman, "Herder's Nineteenth Century," Nineteenth-Century Music Review 7/1 (2010): 3-21; A Companion to the Works of Johann Gottfried Herder, ed. Hans Adler and Wulf Koepke (Rochester: Camden House, 2009); and Matthew Gelbart, The Invention of "Folk Music" and "Art Music": Emerging Categories from Ossian to Wagner (Cambridge: Cambridge University Press, 2007)

${ }^{10}$ G. R. Searle, A New England? Peace and War, 1886-1918 (Oxford: Clarendon Press, 2004). Interdisciplinary literature on the fin de siecle is expansive, with recent "third wave" studies adopting a global perspective. See Fin de siècle and Its Legacy, ed. Mikuláš Teich and Roy Porter (Cambridge: Cambridge University Press, 1990); Cultural Politics at the Fin de Siecle, ed. Sally Ledger and Scott McCracken (Cambridge: Cambridge University Press, 1995); The Cambridge Companion to the Fin de Siècle, ed Gail Marshall (Cambridge: Cambridge University Press, 2007); and The Fin-de-Siècle World, ed. Michel Saler (Abingdon: Routledge, 2015).
} 
to vernacular song, I want to draw attention to what I term the "folkloric imagination"-a conceptual outlook shared by those concerned with the selective preservation of "folk" material in the form of written texts over and above the intricacies of lived experience. The folkloric imagination allowed its practitioners to envisage a mythical and curative past driven by the yearning for an alternative present. ${ }^{11}$ The majority of song collectors, in other words, were more interested in the beguilingly "primitive" quality of the material they sought than in the social experience of popular musicmaking during the nineteenth century.

By drawing out the hitherto neglected ties between folkloric thought and imperialism, moreover, I seek to advocate a postcolonial turn of thought grounded in the work of Michel de Certeau. Folk-song theory shares in what Leela Gandhi describes as a "peculiar habit of mind" prevalent in the imperial metropolis at the fin de siècle: "A complex analogical system relentlessly mapping hierarchies of race, culture, and civilization upon relationships between genders, species, [and] classes." ${ }^{12}$ Reflecting the broader epistemology of colonialism-a worldview striving to uphold a partitioned model of "us" (civilized, modern) and "them" (primitive, premodern)-the concept of folk song relied upon ideals of cultural particularity untainted by intrusions of Otherness. Rather than dwelling on a fear of contamination by non-Western alterity, however, folk-song discourse concerned itself with aesthetic polarizations of (organic, unsullied) rural music against (contrived, degenerate) urban mass culture, and of

\footnotetext{
${ }^{11}$ Building on Benedict Anderson's Imagined Communities: Reflections on the Origin and Spread of Nationalism, rev. edn. (London: Verso, 2006) and extending ideas sketched out by Georgina Boyes in The Imagined Village: Culture, Ideology and the English Folk Revival (Manchester: Manchester University Press, 1993), I intend this term to resonate with what Radano and Bohlman have termed the "racial imagination"; see Music and the Racial Imagination, ed. Ronald M. Radano, Philip V. Bohlman, and Houston A. Baker (Chicago: University of Chicago Press, 2000).

${ }^{12}$ Leela Gandhi, Affective Communities: Anticolonial Thought, Fin-de-Siecle Radicalism, and the Politics of Friendship (Durham, NC: Duke University Press, 2006) 7. See also Jonathan Schneer, London 1900: The Imperial Metropolis (New Haven, CT: Yale University Press, 1999).
}

one country's "innate" musical character against another. As the contrapuntal perspective adopted by writers such as Edward Said, Homi Bhabha, and Paul Gilroy has demonstrated, however, such Manichean thinking is untenable in view of the hybridities arising from globalization and from the profoundly porous or interstitial nature of colonial encounter. $^{13}$ Likewise, it is impossible to square claims made for the unalloyed purity of folk song with a critical genealogy of this material.

Scholars including Robin Kelley, Regina Bendix, and Matthew Gelbart have established that, although folkloric ideals were rhetorically envisioned as the antithesis of technological progress, "premodern" folk culture was constitutively tied up in the fears and desires of a society in the throes of modernization. ${ }^{14}$ The concept of folk culture, Kelley argues, is an example of what Lévi-Strauss termed bricolage: "A cutting, pasting, and incorporating of various cultural forms that"-in this case- "then become categorized in a racially or ethnically coded aesthetic hierarchy." ${ }^{15}$ So understood, folk culture is best viewed as a trope, a disciplinary force striving to refine, homogenize, and control the intricacies of vernacular culture. Frequently called on during periods of upheaval, this Golden Age chimera resurfaces like the transpositions of a ritornello throughout modern history-ultimately revealing itself to be, in Raymond Williams's words, "a myth functioning as a memory." ${ }^{16}$

\footnotetext{
${ }^{13}$ Edward W. Said, Culture and Imperialism (London: Vintage, 1994); Homi K. Bhabha, The Location of Culture (London: Routledge, 2004); Paul Gilroy, The Black Atlantic: Modernity and Double Consciousness (London: Verso, 1993).

${ }^{14}$ Robin D. G. Kelley, "Notes on Deconstructing 'The Folk'," American Historical Review 97/5 (1992): 1400-08; Regina Bendix, In Search of Authenticity: The Formation of Folklore Studies (Madison: University of Wisconsin Press, 1997); and Gelbart, The Invention of "Folk Music." See also The Invention of Tradition, ed. Eric Hobsbawm and Terence Ranger (Cambridge: Cambridge University Press, 1983)

${ }^{15}$ Kelley, "Notes on Deconstructing 'The Folk'," 1402. See Claude Lévi-Strauss, The Savage Mind, trans. Sybil Wolfram (London: Weidenfeld and Nicolson, 1966).

${ }^{16}$ Raymond Williams, The Country and the City (London: Chatto and Windus, 1973), 43. On this theme, see also Joseph Roach, Cities of the Dead: Circum-Atlantic Performance (New York: Columbia University Press, 1996), and
} 
What was unique at the turn of the twentieth century was the foundation of a landmark institution set up on the basis of this trope with the express purpose of collecting, classifying, publicizing, and speculating about folk music-namely, the Folk-Song Society. Those affiliated with this organization were conditioned by ideas and occurrences specific to their time: socialist radicalism, evolutionary philosophy, racial degeneration, the rise of suburbia, and worries over rapidly proliferating mass culture. Their collecting efforts were driven by a sense of alarm that society had reached a terminal state from which it would not recover. Writing in 1892, for instance, Sabine Baring-Gould believed that ballads would soon "be as extinct as the Mammoth and the Dodo, only to be found in the libraries of collectors. ${ }^{17}$ This notion of an irreplaceable thing perpetually at risk of expiring is the emotional linchpin of the folkloric imagination.

\section{The Voice under Erasure}

The work of de Certeau offers a productive way of negotiating the convoluted relationship between historiography, ethnography, and alterity vital to understanding the folkloric imagination. The driving force behind his work is a desire to map topographies of power in relation to those trapped within their vision, aiming to comprehend the ways in which Others have been animated or made to speak from without. ${ }^{18}$ For de Certeau, the discourses that express and circumscribe alterity belong inextricably to historians and ethnographers and not to the objects of their gaze or praxis. All research aimed at the Other must therefore be understood as "the product of a place."19

Benjamin Filene, Romancing the Folk: Public Memory and American Roots Music (Chapel Hill: University of North Carolina Press, 2000).

${ }^{17}$ Sabine Baring-Gould, Strange Survivals: Some Chapters in the History of Man (London: Methuen \& Co., 1892), 219.

${ }^{18}$ See Michel de Certeau, The Mystic Fable, vol.1: The Sixteenth and Seventeenth Centuries, trans. Michael B. Smith (Chicago: University of Chicago Press, 1992), and The Possession at Loudun, trans. Michael B. Smith (Chicago: University of Chicago Press, 2000).

${ }^{19}$ Michel de Certeau, The Writing of History, trans. Tom Conley (New York: Columbia University Press, 1988), 64.
What de Certeau terms the "historical operation" is a scholarly procedure that alters and redistributes the past through a combination of its contingent location, its learned or scientific practices, and the architectural feat of writing (including activities of selection and narrativization). History thus functions as a kind of performative substitute for the past expressed on the terms of the present.

For de Certeau, history and anthropology are united not only by these scriptural practices, but also via an equivalent "staging of the other in present time. ${ }^{\prime 20}$ Whereas history confronts and resurrects the dead (as phantasmic Other), early ethnography orchestrated and aestheticized the primitive (as exotic Other). Both approaches force absent bodies to speak through the mediation of documents and both are "heterologies," that is, hermeneutics of difference based on presumed knowledge of the Other. The stable order produced by Western authors as a result of such historical and ethnographic operations is an illusion. Manifesting "a political will to manage conflicts and to regulate them from a single point of view," its globalizing and universalizing structure resounds with the colonial enterprise. ${ }^{21}$

Viewed in this light, the study of folk song is unmistakably a heterology-an attempt to establish through writing a knowledge of what Richard Middleton has termed the "low Other."22 Relying upon a confluence of colonialist historiography and amateur ethnography, collectors did not simply recover songs from the folk, but rather rearticulated them to serve new and unfamiliar purposes. The evanescent voice of a folk Other within such material was simultaneously present and absent, leaving texts to circle endlessly around an excess they could never fully capture. Despite turning the Tupi people of Brazil, for example, "into a festive body and an

See also Hayden White, The Content of the Form: Narrative Discourse and Historical Representation (Baltimore: Johns Hopkins University Press, 1987).

${ }^{20}$ De Certeau, The Writing of History, 85.

${ }^{21}$ Ibid., 92.

${ }^{22}$ Richard Middleton, "Musical Belongings: Western Music and Its Low-Other," in Western Music and Its Others: Difference, Representation, and Appropriation in Music, ed. Georgina Born and David Hesmondhalgh (Berkeley: University of California Press, 2000), 59-85. 
object of pleasure," de Certeau argues, the travel writing of Jean de Léry could not do justice to the seductive qualities of native speech; what remained were the mere traces of "irrecoupable, unexploitable moments. ${ }^{\prime 23}$ Likewise, when late Victorian collectors turned their attention to vernacular singing, largely via notebooks, periodicals, and published scores, they tended to ignore or unintentionally erase these irrecoupable moments of sonic rapture. What "cannot be uprooted" from such environments, de Certeau affirms, "remains by definition outside the field of research. ${ }^{\prime 24}$ The drawback of such methodologies is thus the very condition of their success. In order to gather, analyze, and classify folk material this material first has to be reified and extracted from its surrounding cultural ecology, effacing the intricate patterns of quotidian meaning and usage along with the initial act of enunciation itself.

All heterologies are unified, de Certeau proposes, by this common characteristic of "attempting to write the voice," which consequently appears in translation and always in the form of a quotation-both in view and yet incomplete. ${ }^{25}$ Thus we might think of the notated score to a collected song representing, in Derridean terms, the voice sous rature or "under erasure," resulting in the following formula: folk song = the voice of the Other. ${ }^{26}$ In this transcribed form, traces of the Other demand or presuppose scholarly exegesis, implicitly positioning an enlightened expert (the collector or theorist) as the interpretive spokesperson for a seemingly unconscious, childlike, or ignorant subject (the singer). ${ }^{27}$ Lodged in written language, these traces of vocality become proxies for an inaccessible somatic presence. The question is just how much of a trace survives the erasure. ${ }^{28}$

\footnotetext{
${ }^{23}$ De Certeau, The Writing of History, 227-28.

${ }^{24}$ Michel de Certeau, The Practice of Everyday Life, trans. Steven Rendall (Berkeley: University of California Press, 1984), 20.

${ }^{25}$ Ibid., 159, 156. See also Richard Middleton, Voicing the Popular: On the Subjects of Popular Music (London: Routledge, 2006).

${ }^{26}$ See Gayatri Chakravorty Spivak, Preface to Jacques Derrida, Of Grammatology, trans. Gayatri Chakravorty Spivak (Baltimore: Johns Hopkins University Press, 1997), xiii-xx.

${ }^{27}$ De Certeau, The Practice of Everyday Life, 160.

${ }^{28}$ The advent of the phonograph, of course, fundamentally altered the question of how to preserve the voice of individual
}

Folk song at the fin de siècle should consequently be viewed as the result of three interrelated factors: first, a particular location within society and time that afforded immersion in concurrent aesthetic, political, and historiographical ideas; second, an ethnographic praxis that rested on the selection and reification of songs as written texts, imposing reclassifications of vernacular material with unconcealed disdain for mass culture; and finally, a heterological discourse that strove to interpret the folk via unsubstantiated theories of origin, survival, and transmission. Effecting an erasure of the singing voice, such work ultimately neglected the complexities of cultural practice in favor of what de Certeau dubs "folklorization" - a process in which a less powerful milieu is purified by an external authority and reduced to a series of fragments in a museum or mausoleum rendered "like a diorama in trompe l'oeil perspective. ${ }^{\prime 29}$ The customs of those unwittingly baptized as "the folk" only ever existed in the minds and imaginations of those with the power to foreclose them. Such traditions are entirely dependent on this asymmetrical rapport. Folk traditions, in other words, do not exist outside the discursive edifice of revivalism. Read in this way, folk song is a deeply unsound reflection of historical experience-a profoundly political set of relations masquerading as an apolitical universal.

\section{Horsham's Grand Old Songster}

Death, paradoxically, is central to a folkloric worldview. Something can be revived, after all, only if it is no longer living. The irony for folk-song enthusiasts at the turn of the century was that the objects of their gaze were still alive at the moment of revival itself-uncanny specters of the past. The following words were

\footnotetext{
singers. The Society was nevertheless divided on the subject at the dawn of the new century. Although championed by Percy Grainger among others, many members were adamantly against the intrusion of such modern technology into their field. See the "Discussion" in Broadwood, "On the Collecting of English Folk-Song," 107-08; Anon., "Folk Song and National Song," Musical Herald 706 (1907): 20-21; and Percy Grainger, "Collecting with the Phonograph," Journal of the Folk-Song Society 3/12 (1908): 147-62.

${ }^{29}$ Michel de Certeau, Culture in the Plural, trans. Tom Conley (Minneapolis: University of Minnesota Press, 1994), 138-39.
} 
dictated by Henry Burstow, "celebrated bellringer and songsinger" of West Sussex, and published in 1911 in the book Reminiscences of Horsham. He was then in his mid-eighties:

I remember, when quite a boy, buying for my mother of a pedlar, as he sang in the street, the old ballad "Just Before the Battle, Mother." This was her favourite song because, I think, her mother's favourite boy, after having fought in many battles, had deserted and fled and was never more heard of. I have sung this song to her many times, never without bringing tears to her eyes; her last request to me as she lay on her death bed (she died 14 $4^{\text {th }}$ March, 1857) was to sing it to her again. It was this occasion-the occasion that comes but once in a lifetime-in which my prospective loss was measured by the depth of a mother's requited love, that I proved most fully the resources of my natural hobby as an outlet for expressions of the tenderest sentiments. I feel as sure as that I am myself awaited by death, that as she lay there, her hand in mine, with this her favourite song in her ear, nothing I could say or do, nor that anyone else could say or do could have better pleased or satisfied her last moments. ${ }^{30}$

Burstow had become somewhat of a local celebrity. A South Coast correspondent for the Musical Herald noted that Horsham's "grand old songster" had presented material at a public band concert at the age of eighty-two. ${ }^{31}$ His customary surroundings, however, tended to be local pubs, "Where song singing was always regularly indulged in during the evenings" throughout the year. ${ }^{32}$ There was "not a village Inn for miles around," he declared, "where I have not sung" and invariably been asked to return. $^{33}$

The son of clay tobacco-pipe makers, Burstow had grown up in poverty; having earned his living as an artisan shoemaker, in old age he narrowly escaped the workhouse

\footnotetext{
${ }^{30}$ Henry Burstow, Reminiscences of Horsham: Being Recollections of Henry Burstow, the Celebrated Bellringer and Songsinger, ed. William Albery (1911; rpt. Norwood, PA: Norwood Editions, 1975), 108-09. Albery was a local saddle-maker, socialist, and amateur historian who recorded Burstow's recollections; all proceeds from the book went to Burstow himself.

${ }^{31}$ "News from All Parts," Musical Herald 721 (April 1907): 107-11, 109.

${ }^{32}$ Burstow, Reminiscences of Horsham, 108

${ }^{33}$ Ibid., 109.
}

through a charitable pension provided by local donations. ${ }^{34}$ A mildly eccentric character dedicated to model making, painting, and local history, Burstow was also known for his vociferous anti-clericalism and commitment to Darwin's ideas on evolution. The twin pastimes of bell ringing and singing, however, had proved to be his greatest pleasures-the latter, as he described it, "My chief mental delight, a delight that has been my companion day after day in my journey from infancy through every stage of life to my now extreme old age. ${ }^{\prime 35}$

Burstow's passing at ninety was announced with sadness in the Musical Herald and accompanied by a touching anecdote: "A few years ago he promised to sing to his wife all the songs he knew, and it took him six weeks, singing ten songs a day ... all from memory." ${ }^{36}$ Burstow himself portrays the scene as follows: "As we sat, evening after evening, one on either side of the fire, as happy as a king and queen, I singing my best, she listening and occasionally herself singing one of the fifty songs I had taught her, the old songs seemed as fresh and as pretty as they did when I first sang them fifty, sixty, perhaps seventy years or more ago. ${ }^{\prime \prime 37}$

Often being able to memorize a lyric on first or second hearing, Burstow had acquired his repertoire of 420 songs from a number of people in a variety of ways. He records these sources in detail: his father, mother, and brother-in-law; local laborers and craftsmen; a sailor, a tailor, and an ex-soldier; the parish clerk; encounters in "taprooms and parlours of public houses in the Towns and Villages round ... where the words of many songs have been taught and learnt, exchanged or sold, for perhaps a pint of beer"; and "ballad sheets I bought as they were being hawked about at the fairs, and at other times from other printed

\footnotetext{
${ }^{34}$ A. E. Green and Tony Wales, foreword, Burstow, Reminiscences of Horsham. The only detailed treatment of Burstow's repertoire to date is Vic Gammon, "'Not Appreciated in Worthing?' Class Expression and Popular Song Texts in Mid-Nineteenth-Century Britain," Popular Music 4 (1984): 5-24.

${ }^{35}$ Burstow, Reminiscences of Horsham, 107.

${ }^{36}$ "News from All Parts," Musical Herald 816 (March 1916): 112-15, 113.

${ }^{37}$ Burstow, Reminiscences of Horsham, 109.
} 
matter. ${ }^{\prime 38}$ New songs, he noted, had also been composed to mark specific occasions or stemmed from the creative flair of his friend Jim Manvell, a Horsham bricklayer. ${ }^{39}$

In Burstow's catalogue we thus find an eclectic assortment of music encompassing broadsides, minstrel songs, Victorian sentimental airs, and other material by British and American writers including Henry Russell, Charles Dibdin, Henry Clay Work, Frederic Weatherly, M. G. Lewis (author of the Gothic novel The Monkl, and Stephen Foster. ${ }^{40}$ Burstow's repertoire, moreover, bore an uncannily close resemblance to contemporary broadsheets. The vast majority of his songs appeared in catalogues for the printers H. P. Such, William Fortey, and Pearson of Manchester. This variety, as Vic Gammon points out, was not unusual for either market town residents or rural singers of the period-attesting to the "fundamental heterogeneity" of nineteenthcentury working-class culture. ${ }^{41}$

Burstow's account bears witness to a long tradition of vernacular singing largely overlooked by musicologists. Mass produced in urban centers and disseminated extensively by networks of itinerant hawkers, printed broadside ballads were central to the history of popular culture. ${ }^{42}$ Comprising, as Adam Fox notes, a

\footnotetext{
${ }^{38}$ Ibid., 107-08.

${ }^{39}$ Ibid., 25, 55, 64, and 108.

${ }^{40}$ Literature on these figures is unfortunately sparse, with the notable exception of Charles Dibdin and Late Georgian Culture, ed. Oskar Cox Jensen, David Kennerley, and Ian Newman (Oxford: Oxford University Press, 2018), and Ken Emerson, Doo-dah! Stephen Foster and the Rise of American Popular Culture (New York: Simon \& Schuster 1997).

${ }^{41}$ Gammon, "'Not Appreciated in Worthing?'” 23. See also Derek B. Scott, Sounds of the Metropolis: The NineteenthCentury Popular Music Revolution in London, New York, Paris, and Vienna (New York: Oxford University Press, 2008), and Street Ballads in Nineteenth-Century Britain, Ireland, and North America: The Interface between Print and Oral Traditions, ed. David Atkinson and Steve Roud (London: Routledge, 2016).

${ }^{42}$ See Christopher Marsh, Music and Society in Early Modern England (Cambridge: Cambridge University Press, 2010) David Atkinson, The English Traditional Ballad: Theory, Method, and Practice (Aldershot: Ashgate, 2002); and Oskar Cox Jensen, "The Travels of John Magee: Tracing the Geographies of Britain's Itinerant Print-Sellers, 1789-1815," Cultural and Social History 11/2 (2014): 195-216. For reproductions, see the University of Oxford's Bodleian Library collection at http://ballads.bodleian.ox.ac.uk and the English Broadside
}

"pervasive feature of the English soundscape" from the Tudor period up to the late nineteenth century, broadsides were pasted up in houses, displayed on alehouse walls, and dispersed around public spaces. ${ }^{43}$ Powerfully shaping rural traditions within what Christopher Marsh describes as a "never-ending process of circulation," these ubiquitous sheets were initially accompanied by an indication of melody (by title only) and illustrative (often stock) woodcuts; later ballads, by contrast, tended to lack indications of melody. ${ }^{44}$ Encompassing a wide variety of topics, broadsides habitually contained songs of courtship, marriage, thwarted or feigned love, sex, satire, religion, and political commentary. Although identified with the vulgar population and much maligned by authorities, such material was also amassed by the elite. During the eighteenth century, for example, the antiquarian Bishop Thomas Percy recovered and amended a selection of popular ballads in a bid to establish a noble heritage of minstrelsy in response to both scurrilous topical singing and the fictitious Scottish bard Ossian, thus helping to lay the foundations of British Romanticism and crystallizing an aesthetic hierarchy echoed in the monumental work of Child. ${ }^{45}$

Rather than descending from ancient bards via an oral tradition, however, these songs had arisen from a promiscuous series of migrations within the commercial print marketplace. ${ }^{46}$ The authorship of ballads was consequently elusive, with texts existing in multiple variants or resulting from collations and borrowings from other literary and musical sources. The idea of folk song subdued this fluid intertextual complexity in favor of a paradigm of organic,

Ballad Archive at the University of California, Santa Barbara http://ebba.english.ucsb.edu.

${ }^{43}$ Adam Fox, "The Emergence of the Scottish Broadside Ballad in the Late Seventeenth and Early Eighteenth Centuries," Journal of Scottish Historical Studies 31/2 (2011): 169-94, 170.

${ }^{44}$ Marsh, Music and Society, 223.

${ }^{45}$ See Nick Groom, The Making of Percy's Reliques (Oxford: Oxford University Press, 1999), and Mary Ellen Brown, Child's Unfinished Masterpiece: The English and Scottish Popular Ballads (Urbana: University of Illinois Press, 2011).

${ }^{46}$ David Atkinson, "Folk Songs in Print: Text and Tradition," Folk Music Journal 8/4 (2004): 456-83. 
unsullied orality. Ironically, the republication of songs by collectors at the fin de siècle concealed the very materiality of the environments from which these songs had been collected.

Although he neither described himself as a folk singer nor identified his repertoire as folk song, Burstow was cast as an epitome of "the folk" as the result of an encounter with one of the foremost collectors of the late nineteenth century. As he tells it:

In 1892-3 I lent my list of songs to Miss Lucy E. Broadwood (later Hon. Secretary and Editor to the Folk Song Society), and sang to her a large number of them, which she noted ... I am glad to know that in these ways have been preserved the words and tunes of nearly all those songs of mine that come within the objects of the Society, viz.: those that are "traditional survivals of songs expressive of the thoughts and emotions of untaught people passing between mind and mind from more or less remote periods to the present time." Some of them have been published, with the tunes harmonized, by Miss Broadwood, and can now be bought in cheap book form. ${ }^{47}$

The quotation-noted in what appears to be an editorial codicil as a definition meeting "with the approval of the Hon. Secretary of the Folk Song Society" - strikes as an intrusion into Burstow's narrative, moderating the complexities of vernacular experience. ${ }^{48}$ Only those songs falling "within the objects of the Society" warranted attention as exemplars of material having survived the passage of time by moving organically among the rural population through an unspecified osmotic process. In this definition (itself mythologized and anonymous like the material it claimed to delineate), songs seemed to have more agency than singers themselves.

Great-granddaughter of the English piano and harpsichord manufacturer John Broadwood, Lucy Broadwood had spent the majority of her life until age thirty-six at the family's country manor house, "Lyne," not far from Horsham on the Surrey-Sussex border. $^{49}$

\footnotetext{
${ }^{47}$ Burstow, Reminiscences of Horsham, 110.

${ }^{48}$ Ibid.

${ }^{49}$ For biographical information, see Dorothy de Val, In Search of Song: The Life and Times of Lucy Broadwood (Farnham: Ashgate, 2011).
}

Funded by a private income, she never married. From 1894 she resided in London, performing as an amateur singer, and extending her musical and ethnological interests through active involvement in both the Purcell Society and the Folk-Lore Society. ${ }^{50}$ As Burstow mentions, Broadwood published a number of songs in 1893 in collaboration with the music critic J. A. Fuller Maitland. In their preface to the volume, entitled English County Songs, Broadwood and Fuller Maitland remarked that their correspondents had been forced to spend "considerable time" persuading regional singers to perform: "The difficulty of getting the oldfashioned songs out of the people is steadily on the increase. ${ }^{\prime 51}$ Once certain elderly singers began, the editors observed, they nonetheless had "a good deal of difficulty in leaving off" as "they are not unnaturally pleased to see their old songs appreciated by anybody in these degenerate days"-a comment to which I shall return. $^{52}$

That same year, Broadwood wrote to the Magazine of Music with an appeal described as being of interest to "students of the science called folklore." ${ }^{153}$ By reason "of a gross and culpable carelessness," it announced, "England has lost most of her folksongs." ${ }^{54}$ Although figures such as Sabine Baring-Gould and Frank Kidson had "rescued" numerous traditional tunes, it continued, "We want these wildflowers of minstrelsy to be systematically and accurately arranged and classified, and, if possible, their inner meaning extracted." 55 The appeal ended with a plea to anyone "who can get hold of an old folksong" to send it to Miss Broadwood, "never mind how stupid its words may seem." ${ }^{\prime 56}$ Aspiring collectors were implored to approach people in order to "get

\footnotetext{
${ }^{50}$ Broadwood's participation in meetings of the Folk-Lore Society is mentioned in "Publications and Proceedings of Archaeological Societies," The Antiquary 27 (April 1893): 169-76.

${ }^{51}$ English Country Songs: Words and Music, ed. Lucy E. Broadwood and J. A. Fuller Maitland (London: Leadenhall Press, 1893), iv.

${ }^{52}$ Ibid.

53"Au Courant," Magazine of Music 10/3 (March 1893): $49-51,50$

${ }^{54}$ Ibid.

${ }^{55}$ Ibid.

${ }^{56} \mathrm{Ibid}$
} 
[songs] out of them" by noting down the words and scoring the tunes, with the aid of a parish organist if musical aptitude was lacking. ${ }^{57}$

To be sure, Broadwood acknowledged that the spread of ballads "was of course due to the pedlars" and that "the existence of various versions of the same tune is a great difficulty in the way of those who would verify their original form. ${ }^{1158}$ Nevertheless, the preface to English County Songs appears torn between a folkloric vision of "tunes that remain among the English peasantry" and the conflicting admission that "districts in which music is largely cultivated among the poorer classes are not those in which the old tunes are most carefully preserved and handed down. ${ }^{\prime 59}$ And indeed Broadwood had collected songs not only from working-class singers such as Burstow but also from her own father and the London musical antiquary A. J. Hipkins, a family friend. ${ }^{60}$

The principal way in which vernacular song was essentialized and transfigured by this songbook, however, was in the harmonization and arrangement of material for trained voice and piano accompaniment, uprooting melodies from their original environment and transporting them, in a new guise, to the middle-class drawing room as neatly notated objects. As Broadwood and Fuller Maitland confess, "While to give the tunes without accompaniment is doubtless the most scientific method of preserving the songs, it has the disadvantage of rendering them practically useless to educated singers. ${ }^{\prime 61}$ The idiom chosen consciously realigned these melodies with the European art song tradition. In several cases, the editors noted, where tunes showed "remarkable affinity with a song of Schubert's, the accompaniment has been treated in more or less his style. ${ }^{\prime \prime 2}$ Not only did Broadwood and Fuller Maitland act as gatekeepers to the vernacular

\footnotetext{
${ }^{57}$ Ibid.

${ }^{58}$ English County Songs, iv, iii.

${ }^{59}$ Ibid., iii, iv. See also Arthur Knevett and Vic Gammon, "English Folk Song Collectors and the Idea of the Peasant," Folk Music Journal 11/1 (2016): 42-64.

${ }^{60}$ E. David Gregory, "Before the Folk-Song Society: Lucy Broadwood and English Folk Song, 1884-97," Folk Music Journal 9/3 (2008): 372-414.

${ }^{61}$ English County Songs, v.

${ }^{62}$ Ibid.
}

by reshaping material in this way, but they also relied upon their own aesthetic inclinations to gather and select the small number of songs published from the total collected. ${ }^{63}$

Broadwood was thus less interested in recuperating the culture of vernacular singing around Burstow than in transcribing, preserving, and disseminating a particular facet of his repertoire that she considered to be more valuable and authentic than the rest. While material deemed "traditional" and aesthetically pleasing was safeguarded as folklore the rest was rendered obsolete and hence invisible. As Maud Karpeles later acknowledged, "The traditional singer . . . does not distinguish between folk songs and other songs in his repertory. ${ }^{\prime 64}$ Published songbooks could never capture the social practices they attested to and necessarily erased a singer's personal tastes, along with experiences such as serenading a mother on her deathbed, listening to a spouse by the fireside, buying and learning a printed ballad, or exchanging material in a local pub. Popular songs had always been imbued with such intimate acts and memories. As de Certeau writes in relation to proverbs and everyday material culture, objects and discourses are marked and manipulated by users, and thereby indicate "a social historicity. ${ }^{\prime \prime 5}$ Through processes of selection, reclassification, notation, and harmonization, the concept of folk song eradicated this social historicity in the same gesture that aimed to extricate the material's "inner meaning."

Key to this project was the widespread belief at the fin de siècle that contemporaneous culture contained and occasionally reproduced remnants of the distant past. The anthropologist E. B. Tylor, for example, had stressed in 1869 that civilized society retained "vestiges of the course of its development" or "modern representatives of pre-historic man" offering clues to the significance of existing cultural mores. ${ }^{66}$

\footnotetext{
${ }^{63}$ See Pamela J. Shoemaker and Tim P. Vos, Gatekeeping Theory (New York: Routledge, 2009).

${ }^{64}$ Maud Karpeles, Cecil Sharp: His Life and Work (London: Faber \& Faber, 2008), 39.

${ }^{65}$ De Certeau, The Practice of Everyday Life, 21.

${ }^{66} \mathrm{E}$. B. Tylor, "On the Survival of Savage Thought in Modern Civilization," Appletons' Journal of Literature, Science and Art 18-19 (1869): 566 and 598, 598.
} 
Broadwood was conversant with such ideas, having participated in discussions at the Folk-Lore Society-one, in particular, during which the antiquarian T. F. Ordish presented a paper arguing that Mumming plays "place us in contact with the pagan beliefs and rites of our northern and Teutonic forefathers. ${ }^{\prime \prime 7}$ Broadwood's colleague Baring-Gould, moreover, had published a book on the subject in 1892 offering interpretations of curious customs from architecture and riddles to dolls, etiquette, and the gallows. Relying on the idea that "survivals" provided a link "to a period when all men were children" and likewise to "savage races" with "low mental condition" (the example given is sub-Saharan Africans), the patient research "of the comparative mythologist and ethnologist," Baring-Gould insisted, enabled European customs to be deciphered. $^{68}$

Equating "primitive" culture with infancy and strata of the deep past, the folkloric imagination was saturated with the hierarchies of colonialist epistemology. Whether guardians or inventors of song, the folk were trapped in a childlike state of purity, representative of humanity before it had attained the full powers-and experienced the most unfavorable consequences-of enlightened rationality. By projecting this structure onto the milieu they aimed to document, in lieu of embracing its values, collectors at the fin de siècle generated a taxonomy entirely at odds with their field of inquiry. Alleged to contain premodern survivals, vernacular singing, we might say, was hijacked by the modern discourse of folk song.

\section{Down in the Black Horse}

In late January 1898 a meeting chaired by Alfred Nutt, President of the Folk-Lore Society, convened in the rooms of the Irish Literary Society in central London. Among those present were Broadwood, Fuller Maitland, and the professional contralto Kate Lee. ${ }^{69}$ As reported in the Manchester Guardian, the purpose of this meeting was "to discuss the for-

\footnotetext{
${ }^{67}$ "Publications and Proceedings," 172.

${ }^{68}$ Baring-Gould, Strange Survivals, 127, 143-44, 61.

${ }^{69}$ "Our London Correspondence," Manchester Guardian, 28 January 1898, 5.
}

mation of a Folk-Song Society, having for its object the preservation of the traditional songs of the United Kingdom..$^{170}$ Letters of commendation were read from the antiquarian Frank Kidson as well as such musical luminaries as Sir Charles Villiers Stanford, Sir Alexander Campbell Mackenzie, and Sir George Grove. The scientific work this new group desired to undertake-a report in the Musical News declared-was the "collecting and preserving [of] specimens of folk-song." ${ }^{71}$

The Society was officially constituted in June. By early 1899 it boasted a membership of over one hundred, funds of over forty pounds, and four Vice Presidents including the Principal of the Royal Academy of Music, the Director of the Royal College of Music, and Professors of music from the Universities of Oxford and Cambridge. ${ }^{72}$ The ambitions of this organization were twofold: first, to discover, collect, and publish material; and second, to be a forum for performances, lectures, and discussions. Applauding these aims in the Musical Standard, the critic Edward Baughan suggested that if proceedings of the Society were to be published, "It might be well to give the original notation of the member who took down any folk song side by side with a suggested adaptation or restoration, or whatever you like to call a folk song in its cooked-up form." ${ }^{73}$ In an oddly oblique way, Baughan's advice was heeded. When the Society began publishing its Journal, strophic melodies were printed (albeit in conventional notation) without harmonization; when these songs were presented at meetings, however, "cooked-up" versions performed by members of the Society supplanted these published "specimens."

Recognized in her obituary as "the virtual founder of the Folk-Song Society," Lee had been elected as Honorary Secretary and was known for delivering lectures on her own rather audacious collecting work. $^{74}$ An

\footnotetext{
${ }^{70}$ Ibid.

${ }^{71}$ J. E. B. "Comments on Events," Musical News 14/362 (1898): 126-29, 129.

${ }^{72}$ Journal of the Folk-Song Society 1/1 (1899): i-viii.

${ }^{73}$ Edward Baughan, "Comments and Opinions," Musical Standard 9/214 (1898): 80.

"74"The Late Honorary Secretary," Journal of the FolkSong Society 2/6 (1905): 67.
} 
embodiment of fin-de-siècle feminism, Lee spoke not only at the Society's inaugural conversazione, but also at the 1899 International Congress of Women, where she "gave an amusing account of the difficulties she experienced in collecting folk-songs, and she besought her audience to help to collect airs from country people before they sank out of recollection." ${ }^{\prime 75}$ Described by the Musical Herald as "a lady of winning personality" who could "equally well get to the heart of an old longshoreman or of an aristocratic audience at the West End," Lee did not restrict her ethnography to rural locations. She believed that traditional songs also survived in towns and cities among "those who have left their homes" and were less suspicious of outsiders than country dwellers. ${ }^{76}$

One of Lee's most humorous anecdotes involves "a very old lady living in the East of London" whom she characterizes as "a veritable storehouse of folk-songs":

I had qualms when she first threatened to come and sing to me; I thought she might be a burglar in disguise, so when she arrived I took down songs with one eye on the umbrellas and the other on the paper, but she did not take anything, although she left, I think, a good deal. She said that she hadn't ever visited a real lady before, but "that I wasn't the least bit like one." This was, of course, a sort of back-handed compliment, at least I took it to be so. ${ }^{77}$

Tracing the origin of such tunes, Lee observed, was nonetheless extremely difficult, as "the same song would be heard, with slight variations, in different districts. ${ }^{178}$ A further trouble Lee encountered when attempting to notate melodies in rural areas was what she described as "the monotonous, expressionless, rapid way of the country singers, who stood upright, and looked fixedly in front of them" or

\footnotetext{
${ }^{75}$ "Musical Matters at the International Congress of Women," School Music Review 8/87 (1899): 45-46, 46 See also Gillian Sutherland, In Search of the New Woman: Middle-Class Women and Work in Britain 1870-1914 (Cambridge: Cambridge University Press, 2015).

${ }^{76}$ "Experiences of a Folk-Song Collector," Musical Herald 612 (March, 1899): 71.

${ }^{77}$ Kate Lee, "Some Experiences of a Folk-Song Collector," Journal of the Folk-Song Society 1/1 (1899): 7-12, 10.

"88 "Experiences of a Folk-Song Collector."
}

sometimes sang alternate verses as a duet, producing a "distinctly comic" effect. ${ }^{79}$

Lee had begun collecting songs in "a little seaport town in the north of Norfolk, not patronised by tourists, and with no special attraction of any sort, except fresh air and level roads" (suitable for her bicycle) named Wellsnext-the-Sea. ${ }^{80}$ One morning while wandering along the Quay she plucked up the courage to confront four elderly fishermen whose faces had become familiar during her promenades:

They told me I had better find "Tom C_-," whose aunt, they thought, "sang old songs, but was dead," but that, no doubt, Tom himself could sing them if I liked to hear them. Tom was sent for and told to call on me in the evening, and he came, dressed up in his best, and shaking with fright. He said he thought he could sing, but when he began he was so frightfully nervous that not a note could he utter, and he gave way to groans, interspersed with whistling when he got anywhere near the air, and I almost gave up the idea as hopeless after hearing him, although I took down one tune which was fairly good, which, as I afterwards found from Mr. Frank Kidson, was not traditional. However, he told me the names of several songs that had been sung in Wells in times gone by, one especially I remember the name of, which was "The Wreck of the Princess Royal." I did not take down this song, because the title had a modern sound, but I afterwards found out that I had made a great mistake. ${ }^{81}$

Tom, in turn, had directed her to an exsoldier and veteran of the Opium Wars by the name of Edge, from whom she collected a song "decidedly Welsh in character. ${ }^{182}$ Lee's account foregrounds such hybrid and transnational qualities in popular music, noting, for example, the presence of "Scotch" melodies in the West of Ireland-a place where she found, to her evident surprise, that "few people sang Irish songs." ${ }^{\prime 83}$ Such findings would create trouble when the folk-song movement began to take on a more determinedly nationalistic bearing under Cecil Sharp. ${ }^{84}$

\footnotetext{
${ }^{79}$ Ibid.

${ }^{80}$ Lee, "Some Experiences," 8.

${ }^{81}$ Ibid., 8-9.

${ }^{82}$ Ibid., 9 .

${ }^{83}$ Ibid., 10.

${ }^{84}$ On this phase of the revival under Sharp's influence, see Ross Cole, "On the Politics of Folk Song Theory in Edwardian England," Ethnomusicology 63/1 (2019), in press.
} 
Published in the first issue of the Journal of the Folk-Song Society, Lee's lecture also includes remarks on her successful collection of material from the now celebrated Copper brothers of Rottingdean, a coastal village near Brighton:

I shall never forget the delight of hearing the two Mr. Coppers . . . they were so proud of their Sussex songs, and sang them with an enthusiasm grand to hear, and when I questioned them as to how many they thought they could sing, they said they thought about "half a hundred." You had only to start either of them on the subject of the song and they commenced at once. "Oh, Mr. Copper, can you sing me a love song, a sea song, or a plough song?" It did not matter what it was, they looked at each other significantly, and with perfectly grave faces off they would go. Mr. Thomas Copper's voice was as flexible as a bird's. He always sang the under part of the song like a sort of obbligato, impossible, at first hearing, to put down. ${ }^{85}$

Along with his elder brother James "Brasser" Copper, Thomas had worked as a farm laborer in rural Sussex most of his life; by the time of Lee's visit in 1898, however, he had become the landlord of a small public house. ${ }^{86}$ As his greatgrandnephew later documented, during his time as a publican Thomas had "formed a team of hand-bell ringers, kept the traditional Mummer's Play alive, and was the host to a gathering of all the old village singers every Saturday night. ${ }^{187}$ In transcribing their material, Lee declares, "I simply tired out the two Mr. Coppers after three evenings' hard work. ${ }^{\prime \prime 8}$ The result was six songs published in the Society's Journal. If such tunes were "left to take care of themselves in the villages," Lee concluded, "how soon will they die and be heard no more"; she hoped that members would thus "find their way down to the piers and quays before the old fishermen have gone out with the tide. ${ }^{\prime \prime 99}$

\footnotetext{
${ }^{85}$ Lee, "Some Experiences," 10-11.

${ }^{86}$ Bob Copper, A Song for Every Season: A Hundred Years of a Sussex Farming Family (London: Heinemann, 1971), 11. There are some minor discrepancies between Lee's account and that of Bob Copper; for clarification, see Vic Gammon, "Copper family (per. 1845-2000)," Oxford Dictionary of National Biography (Oxford: Oxford University Press, 2004) http://www.oxforddnb.com/view/article/76466, accessed 20 June 2016

${ }^{87}$ Copper, A Song for Every Season, 11.

${ }^{88}$ Lee, "Some Experiences," 11.

${ }^{89}$ Ibid., 12.
}

Aside from these brief sketches Lee reveals little about the lives of the individuals from whom she collected. Bob Copper's retrospective account affords a rare view from the perspective of the singers themselves:

Mrs Kate Lee came to the village to stay at Sir Edward Carson's house up at Bazehill. She had heard of James and Tom singing their old songs down in the Black Horse and, wishing to learn more about them, invited them up to the big house one evening. They put on their Sunday clothes and went along. Any embarrassment they might have felt at being asked to sing in front of a lady in an elegantly furnished drawing-room instead of at home in the cottage or in the tap room of the "Black 'un" was soon dispelled by generous helpings from a full bottle of whisky standing in the middle of the table with two cut-glass tumblers and a decanter of water. They sang, they drank and sang again and all the time Mrs Lee was noting down the words and music of their efforts. They kept this up all evening and were not allowed to leave until the bottle on the table was empty and the book on Mrs Lee's lap was full. After several more evenings, proceeding on the same lines as before only with different songs, she returned to London with what was later referred to as a "copper-ful" of songs. ${ }^{90}$

Although the two men were made Honorary Members of the Folk-Song Society for their contributions, the cultural disparity between Lee and the Copper brothers is unmistakable, compounded by the asymmetry of subject and spectator. Much as Broadwood was with Burstow, Lee was drawn to James and Thomas primarily as repositories of material that could be carried in written form from the countryside to the metropolis as intriguing tokens of folklore. Rather than showing interest in the brothers' environment, in other words, Lee viewed the Coppers much as Thomas Percy had viewed his apocryphal folio, saved from the flames of obsolescence not for their intrinsic worth but for the content they conveyed.

Reading Lee's and the Coppers' accounts against each other exposes a telling perceptual disjunction, as if the Coppers had provided a photographic negative of Lee's perspective. Uprooted from both pub and cottage and held captive in a country house by an unfamiliar

\footnotetext{
${ }^{90}$ Copper, A Song for Every Season, 12.
} 
woman of higher social status, the Coppers were requested to sing in a manner wholly foreign to their quotidian experience while wearing clothes ordinarily reserved for church. Although the bottle of whisky was plainly an indispensable provision, Lee tactfully omits to mention it. The uncomfortable environment, moreover, played a decisive role in James and Thomas's choice concerning which songs to offer. As Broadwood admitted, self-censorship regarding anticipated vulgarity "makes it hard for a woman to collect" because "the singer is far too kind to offend her ears, but is almost always unable to hum or whistle an air apart from its words. ${ }^{\prime \prime 1}$

Lee's account of meeting the Coppers-the only one made public at the time-inadvertently forms a portrait of a collision between unequal cultural spheres, one of which was denied its own voice save through acts of gatekeeping substantiated by the folkloric imagination. In spite of her good intentions, Lee's ethnographic praxis erased the vernacular practices she encountered. Formulated without consultation with the singers, her aesthetic judgments held the power to determine what was "traditional" and what was not. The "folk" themselves could not be trusted, it seemed, with the propagation or categorization of their own songs.

Members of the Society, as noted, were interested not only in publishing folk songs as scientific specimens, but also in composing arrangements intended for refined performances in the very social settings that made Tom $\mathrm{C}$. and the Coppers feel so uncomfortable. Held at 7 Chesterfield Gardens in London's Mayfair-the lavish residence of Rachel Beer, born in India to the merchant Sassoon dynasty and later editor (as well as owner with her invalid husband Frederick) of both the Observer and the Sunday Times - the first general meeting of the Society in February 1899 featured Lee singing a number of the Copper brothers' songs with piano accompaniment provided by Fuller Maitland. ${ }^{92}$ Accord-

\footnotetext{
${ }^{91}$ Lucy E. Broadwood, "On the Collecting of English FolkSong," Proceedings of the Musical Association 31 (1904-05): 89-109, 101

92“A Folk-Song Function," Musical Times 40/673 (1899): 168-69; Vanessa Curney, "Beer [née Sassoon], Rachel
}

ing to the Musical Standard, this "very successful evening" attracted around 250 guests. ${ }^{93}$ After the "continuous laughter" occasioned by Lee's "very solid and useful" paper, this article stated, her performance of "The Claudy Banks," presented as a duet with the baritone Charles Phillips, was the "most applauded" performance of the night. ${ }^{94}$ The audience was thus granted access to the Copper brothers' songs only via a chain of mediations in which the songs were filtered, notated, arranged, and restaged by a group of metropolitan folk-song devotees. Performing in the place of an absent "folk," these figures brought to life an essentialized simulacrum of the vernacular on their own terms.

In thus staging an imitation of the Other through stereotype folk-song revivalists were participating in what Robert Cantwell has termed "ethnomimesis," festive rituals of mimicry that occur at the boundaries of groups, classes, or cultures. ${ }^{95}$ Folk song in this context becomes the vehicle of an imaginative misconstrual set at an intersection of high and low where musical performance brings a new social collectivity into existence. ${ }^{96}$ Crucially, however, the very people branded as bearers of folk song by the creators of this milieu neither used nor identified with the term. Once it is spoken, as de Certeau points out, such a language nevertheless "implies points of reference, sources, a history, an iconography" -in short, "a construction of 'authorities." ${ }^{\prime \prime 97}$ In England, the Folk-Song Society became one such authority, articulating a linguistic

(1858-1927)," Oxford Dictionary of National Biography (Oxford: Oxford University Press, 2004). http://www. oxforddnb.com/view/article/48270, accessed 20 June 2016.

93" The Folk-Song Society," Musical Standard 11/267 (February, 1899): 81 .

${ }^{94}$ Ibid.

${ }^{95}$ Robert Cantwell, Ethnomimesis: Folklife and the Representation of Culture (Chapel Hill: University of North Carolina Press, 1993). See also Tamara E. Livingston, "Music Revivals: Toward a General Theory," Ethnomusicology 43/1 (1999): 66-85, and The Oxford Handbook of Music Revival, ed. Caroline Bithell and Juniper Hill (New York: Oxford University Press, 2014).

${ }^{96}$ See Kay Kaufman Shelemay, "Musical Communities: Rethinking the Collective in Music," Journal of the American Musicological Society 64/2 (2011): 349-90, and Ceri Owen, "Making an English Voice: Performing National Identity during the English Musical Renaissance," Twentieth-Century Music 13/1 (2016): 77-107.

${ }^{97}$ De Certeau, Culture in the Plural, 11. 
iconography based on "the folk" and their "folk song." The work of its collectors, based on the production of written documents exiled from their sources in practice, sought, as de Certeau asserts, "to confer upon them the status of 'abstract' objects of knowledge. ${ }^{\prime \prime 98}$ Rather than retrieving source data, such work constitutes its data "through concerted actions which delimit it by carving it out from the sphere of use," pushing it "beyond the limits of use" and ultimately creating the possibility for an entirely new history to be written. ${ }^{99}$ De Certeau thereby directs us toward the idea that collecting refers not to the discovery, but instead to the manufacture of objects through classification and the arrogation of material culture in accordance with contingent intellectual motivations.

\section{A Wholesome and Seasonable Enterprise}

But what were these motivations? A clue is provided by the passing allusion to "degenerate days" in the preface to English County Songs. The increased attention shown to folk song at this time testifies not only to genteel curiosity and personal idiosyncrasy but also to a seam of deeper and more disquieting anxiety peculiar to the fin de siècle. At the opening of his Inaugural Address as a Vice-President of the Society, Sir Hubert Parry brought such issues vividly to the fore:

Ladies and Gentlemen.-I think I may premise that this Society is engaged upon a wholesome and seasonable enterprise. For, in these days of high pressure and commercialism, when a little smattering of knowledge of the science of heredity impels people to think it is hopeless to contend against their bad impulses because they are bound to inherit the bad qualities of countless shoals of ancestors, there is a tendency with some of us to become cynical. ${ }^{100}$

The "best remedy available," he claimed, was to "revive a belief in, and love of our

\footnotetext{
${ }^{98}$ De Certeau, The Writing of History, 73.

${ }^{99}$ Ibid.

${ }^{100}$ Hubert Parry, "Inaugural Address," Journal of the Folk-Song Society 1/1 (1899): 1-3, 1. For biographical information, see Jeremy Dibble, C. Hubert H. Parry: His Life and Music (Oxford: Clarendon Press, 1992).
}

fellow-creatures" through the study of folk music. ${ }^{101}$ In "true folk-songs," he contends, there is nothing "common or unclean ... no sham, no got-up glitter, and no vulgarity."102 These "treasures of humanity" were becoming ever more rare, as they are "written in characters the most evanescent you can imagine, upon the sensitive brain fibres of those who learn them and have but little idea of their value." ${ }^{103}$ The Society existed to rescue this precious material from degeneration just as folk song itself might resuscitate a culture allegedly on the brink of ruin.

For Parry, the primary agent of decay in this profligate world of commercialism was urban popular music - a symptom of the exponential growth in retail, leisure, and mass entertainment industries around the fin de siècle. Driven by a small but significant rise in real working-class wages, this growth encompassed everything from music hall variety theater to sensationalist newspapers, penny novels, soccer, and gambling. Parry's contempt was unequivocal:

There is an enemy at the doors of folk-music which is driving it out, namely, the common popular songs of the day; and this enemy is one of the most repulsive and most insidious. If one thinks of the outer circumference of our terribly overgrown towns where the jerry-builder holds sway; where one sees all around the tawdriness of sham jewellery and shoddy clothes, pawnshops and flaming gin-palaces; where stale fish and the miserable piles of Covent Garden refuse which pass for vegetables are offered for food-all such things suggest to one's mind the boundless regions of sham. It is for the people who live in these unhealthy regions-people who, for the most part, have the most false ideals, or none at all-who are always struggling for existence, who think that the commonest rowdyism is the highest expression of human emotion; it is for them that the modern popular music is made, and it is made with a commercial intention out of snippets of musical slang. ${ }^{104}$

The unrefined conduct and counterfeit commodities of "the seething towns" risked

\footnotetext{
${ }^{101}$ Parry, "Inaugural Address," 1.

${ }^{102}$ Tbid.

${ }^{103}$ Ibid.

${ }^{104}$ Ibid., 1-2.
} 
jeopardizing the bucolic folk. ${ }^{105}$ In this vision, mass culture spread like a virus, infecting the enfeebled and unhealthy population with the disease of industrialized modernity. By contrast, Parry expounded, "Folk-music is among the purest products of the human mind" because it "grew in the hearts of the people before they devoted themselves so assiduously to the making of quick returns." ${ }^{106}$ As an extension of the natural world, folk song flourished in this Edenic nursery before capitalism brought on the Fall. It was artisanal, organic, and self-sufficient.

Such music, moreover, was "characteristic of the race, of the quiet reticence of our country folk, courageous and content . . . and, as a faithful reflection of ourselves, we needs must cherish it." ${ }^{107}$ Folk song thus became the mirror of an idealized political community. In consequence, it harbored pertinent material for composers of the so-called English Musical Renaissance. Folk heritage, Parry declares, provided "the ultimate solution of the problem of characteristic national art." ${ }^{108}$ True style, he maintains, is not individual, but stems from "crowds of fellow-workers, who sift, and try, and try again, till they have found the thing that suits their native taste. ${ }^{1109}$ Folk song was thus the great social-and potentially even socialist-leveler, cutting across class divisions to unite the nation as a new utopian polis. Indeed, Parry elucidates the political motivation underpinning the Society's foundation: "To comfort ourselves by the hope that at bottom, our puzzling friend, Democracy, has permanent qualities hidden away somewhere, which may yet bring it out of the slough which the scramble after false ideals, the strife between the heads that organise and the workmen who execute, and the sordid vulgarity of

\footnotetext{
${ }^{105}$ Ibid., 2

${ }^{106}$ Ibid.'

${ }^{107}$ Ibid.

${ }^{108}$ Ibid., 3. See Meirion Hughes and Robert Stradling, The English Musical Renaissance, 1840-1940: Constructing a National Music (Manchester: Manchester University Press, 2001). For an extended critique of racialized nationalism, see Paul Gilroy, Against Race: Imagining Political Culture Beyond the Color Line (Cambridge, MA: Belknap of Harvard University Press, 2000).

${ }^{109}$ Parry, "Inaugural Address," 3.
}

our great city-populations, seem in our pessimistic moments to indicate as its inevitable destiny." ${ }^{\prime 110}$

Affording joy through "the simple beauty of primitive thought," folk song appeared to lay bare the unshakable bedrock of humanity as a result of "emotions which are common to all men alike." ${ }^{111}$ Hidden away in folk song, consequently, was the source of economic parity, brotherhood, and social(ist) rejuvenation.

What has tended to pass without notice is how such ideas point toward Parry's intellectual affinity with the heterogeneous politics of fin-de-siècle radicalism. His daughter Dorothea stressed that even though he epitomized a life of privilege, Parry was in fact "naturally unconventional . . . a Radical, with a very strong bias against Conservatism" who counted both William Morris and Edward Burne-Jones among his close friends. ${ }^{112}$ The influence of these two figureheads of the Arts and Crafts Movement (some fifteen years older than Parry himself) was evident not only in a small decorative monochrome print depicting entwined lilies adorning the published text of his address (plate 1), but also in his reformist elevation of organicism, communal tradition, and integrity over laissez faire economics and the supposed deterioration of public culture. ${ }^{113}$ Although opposed to aestheticist individualism, Parry's address shares in Oscar Wilde's socialist conviction that society could be restored to full health by "substituting cooperation for competition" and liberating art from the tyrannizing "vulgarity and stupidity" of commercial popular taste. ${ }^{114}$ Parry's vision of democracy

\footnotetext{
${ }^{110}$ Ibid.

${ }^{111}$ Ibid.

${ }^{112}$ Dorothea Ponsonby, "Hubert Parry," Musical Times 97/ 1359 (1956): 263. Parry's views fell within the tradition of "Romantic socialism" in Britain. See Anna Vaninskaya, "Janus-Faced Fictions: Socialism as Utopia and Dystopia in William Morris and George Orwell," Utopian Studies 14/2 (2003): 83-98, and Caroline Arscott, William Morris and Edward Burne-Iones: Interlacings (New Haven, CT: Yale University Press, 2008).

${ }^{113}$ See Rosalind P. Blakesley, The Arts and Crafts Movement (London: Phaidon, 2006).

${ }^{114}$ Oscar Wilde, "The Soul of Man under Socialism" [1891] in Oscar Wilde, The Soul of Man under Socialism and Selected Critical Prose, ed. Linda Dowling (London: Penguin, 2001), 128, 146. See also John Carey, The Intellectuals and the Masses: Pride and Prejudice among the
} 


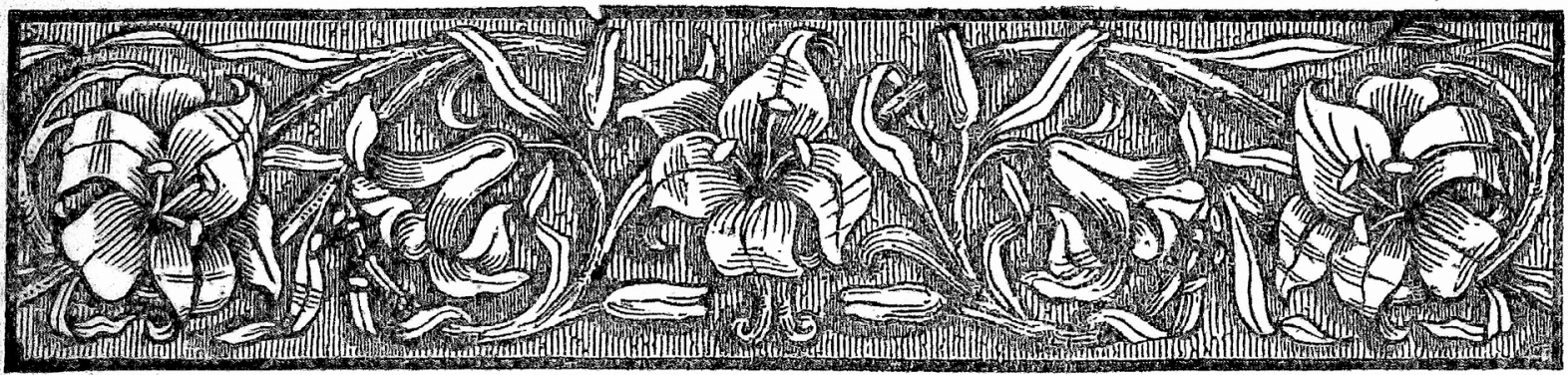

Plate 1: Decorative illustration accompanying Hubert Parry's "Inaugural Address" in the first issue of the Journal of the Folk-Song Society (1899): 1.

likewise echoed Morris's portrait of an egalitarian society "in which there should be neither rich nor poor, neither master nor master's man, neither idle nor overworked, neither brain sick brain workers, nor heart sick hand workers." ${ }^{115}$ Significantly, the folkloric imagination reflected Morris's two most profound passions: a love of "beautiful things" and a nostalgic "repulsion to the triumph of civilization."116 For Morris, prosperous modern society was merely a "sordid, aimless, ugly confusion," a distressing harbinger of future evils it would bring about "by sweeping away the last survivals of the days before the dull squalor of civilization had settled down on the world. ${ }^{\prime 117}$

Rereading Parry's address in this light also reveals a clear indebtedness to literary Romanticism. The idea of reviving "love and wellthinking of our fellow-creatures" via an embrace of country life recalls the title Wordsworth gives to Book 8 of The Prelude: "Retrospect-Love of Nature Leading to Love of Man" (text of 1850). ${ }^{118}$ It is almost as if Parry were consciously paraphrasing the opening of the Book's second stanza, in which the poet reflects on his unhappy sojourn in London:

With deep devotion, Nature, did I feel

In that great City what I owed to thee,

Literary Intelligentsia, 1880-1939 (London: Faber and Faber, 1992).

${ }^{115}$ William Morris, How I Became a Socialist (London:

Twentieth Century Press, 1896), 9.

${ }^{116}$ Ibid., 11.

${ }^{117}$ Ibid., 12.

${ }^{118}$ Parry, "Inaugural Address," 1.
High thoughts of God and Man, and love of Man,

Triumphant over all those loathsome sights Of wretchedness and vice. ${ }^{119}$

Reverberating through the writings of the Transcendentalists, the legacy of Romantic thought afforded the folk-song movement many of its key philosophical tenets. In Walden, for instance, Thoreau laments that due to the market "the laboring man ... has no time to be anything but a machine" in the service of capital, a situation antithetical to "the finest qualities of our nature," which, "like the bloom on fruits, can be preserved only by the most delicate handling. ${ }^{1120}$ For Parry, folk song was precisely this tantalizing bloom, an organic manifestation of humanity's finest qualities threatened by materialism and the entrenchment of Victorian industry.

Much like the Transcendentalists, the folksong collectors united in a crusade against the social ills of nineteenth-century capitalism by elevating nature into a crucible of signs pointing toward a higher state of being. The resulting discourse goes some way toward explaining why the childlike or innocent qualities of folk song were so greatly prized by revivalists. As Emerson writes, "The lover of nature is he whose inward and outward senses are still truly adjusted to

\footnotetext{
${ }^{119}$ William Wordsworth, The Major Works, ed. Stephen Gill (Oxford: Oxford University Press, 2008), 488. More broadly, see Maureen N. McLane, Balladeering, Minstrelsy, and the Making of British Romantic Poetry (Cambridge: Cambridge University Press, 2008).

${ }^{120}$ Henry David Thoreau, Walden, ed. Jeffrey S. Cramer (New Haven, CT: Yale University Press, 2004), 5.
} 
each other; who has retained the spirit of infancy even into the era of manhood." ${ }^{121}$ Folk song represented this delight in primitive natural forms as a restorative balm that would in turn inspire the production of art. For Emerson, art is "nature passed through the alembic of man"-a domain suffering corruption "when simplicity of character and the sovereignty of ideas" is disturbed by "the desire of riches, of pleasure, of power, and of praise." ${ }^{\prime 22}$

Although folk-song theory echoed Morris's evangelical socialism in the guise of "love of the earth and the life on it," combined with "passion for the history of the past of mankind" and with hostility toward capitalist expansion, the vision of democracy it projected appeared less concerned with politics per se than with aesthetics. ${ }^{123}$ Rather than hunger for practical activism or a demonstrable change in position for the working class, Parry's address betrayed an elitist pastoralism in which romanticized products of the rural folk were ranked as superior to what his acquaintance Herbert Spencer vilified as "miserable drawing-room ballads and vulgar music-hall songs." ${ }^{\prime 24}$

A paradoxical politics therefore lay dormant under the surface, an ethical utopianism mistrustful of urban populism and of its reflection in the flourishing mass culture of an "unregenerate public." ${ }^{\prime 25}$ The community Parry wished to see involved a peaceable unification of artists and docile country dwellers in place of the liberal economics generating both wealthy industrialists and "workmen who execute" - in another guise, the potentially threatening forces of unionized labor. The Folk-Song Society thus represented a flight away from socio-economic antagonism within the body politic-the "strife" Parry depicts between head and hands-in the service of a mythical and classless national iden-

\footnotetext{
${ }^{121}$ Ralph Waldo Emerson, "Nature" [1836] in Ralph Waldo Emerson, Nature and Selected Essays, ed. Larzer Ziff (New York: Penguin, 2003), 38.

${ }^{122}$ Tbid., 47, 51 .

${ }^{123}$ Morris, How I Became a Socialist, 12.

${ }^{124}$ Herbert Spencer, "The Origin of Music," Mind 15/60 (1890): 449-68, 465.

${ }^{25}$ Parry, "Inaugural Address," 1. Similar themes are explored in Julian Onderdonk, "The Composer and Society: Family, Politics, Nation," in The Cambridge Companion to Vaughan Williams, ed. Alain Frogley and Aidan J. Thomson (Cambridge: Cambridge University Press, 2013), 9-28.
}

tity secured through a shared musical past. Folk revivalism was shot through with such contradictions, its political vision at once radical and reactionary-elevating (as "folk") and demonizing (as "mass") different facets of the workingclass population.

Underpinning these anxieties regarding mass culture, unchecked capitalism, and deteriorating popular taste was the long fallout from rural depopulation and trepidation over inner-city congestion, poverty, and sanitation. As the essayist Sidney J. Low remarked in the Contemporary Review in 1891, "Depletion of the rural districts is a fact which is not to be disputed ... [England's] life-blood is being drained from the surrounding country-side" into mining and manufacturing districts and also into the maelstrom of Greater London. ${ }^{126}$ To many people, he continued, this "revolution has seemed one which has nothing to relieve its disaster and gloom":

We have thought of the agricultural laborer converted into a town-dweller, the yokel torn from his hamlet to live in the sweltering black slums of the East-end of a great city. The limbs that were "made in England" - on its healthy ploughlands and fresh meadows-must stunt and dwindle in narrow courts and filthy alleys; the children, who should have pulled the honeysuckle in the lanes and hunted for birds' nests in the hedges, will tumble in the gutter outside the public-house. As the process continues, almost the whole population will be jammed into some score of monster towns ... and tens of millions will be exposed to the physical and mental blight of the "submerged" slum-dweller. ${ }^{127}$

What was occurring during the 1890s, however, was an unprecedented movement away from such areas into the suburbs. This new demographic trend formed the primary impetus behind Parry's concern with urban degeneracy.

Drawing on the recently published Census Report, Low noted that inner-city slum dwellers "are obeying the great law of centrifugal attraction, and quitting the inner recesses of the metropolis to find new homes in the

\footnotetext{
${ }^{126}$ Sidney J. Low, "The Rise of the Suburbs: A Lesson of the Census," Contemporary Review 60 (October 1891): 545-58, 546-47.

${ }^{127}$ Ibid., $547-48$.
} 
outskirts." ${ }^{128}$ The suburbs, he affirmed, represented the future of the city across the developed world as segments of the working class and lower-middle-class population colonized new areas of overflow within commutable distance of their employment. The country's lifeblood was therefore in truth "pouring into the long arms of brick and mortar and cheap stucco that are feeling their way out to the Surrey moors, and the Essex flats, and the Hertfordshire copses"; not one, Low aptly predicted, "but a dozen Croydons will form a circle of detached forts round the central stronghold" of the capital. ${ }^{129}$

Whereas Low believed this resettlement would mitigate any unease caused by the "great exodus from the fields" and should not be cause for embarrassment, folk-song devotees saw a very different picture. ${ }^{130}$ A review of the Society's inaugural meeting in the Manchester Guardian singled out Parry's likening of "the latest abomination from the musichalls" to a "jerry-built slum suburb" for praise, extending this metaphor by suggesting that folk song was accordingly "a noble memorial of the past." ${ }^{\prime 131}$ A similar piece in the Musical Standard praised Parry's "eloquent and forcible comparison," noting that his address "was naturally much applauded."132 Refusing to be reconciled with a thoroughly urbanized population, Parry was one of those critics who, in Low's words, inquire with dismay "where the strength and stamina of the race will go" and "regard this abandonment of the land as something abnormal, unnatural, and as it were accidental, which ought not to be accepted as a permanent condition. ${ }^{1133}$ Indeed, the crux of Parry's argument relied upon mapping what had previously been associated only with noxious inner-city environments onto these newly built suburbs, now also branded as slums and

\footnotetext{
${ }^{128}$ Ibid., 550.

${ }^{129}$ Ibid., 550, 551.

${ }^{130}$ Ibid., 552 .

131"Our London Correspondence," Manchester Guardian 3 February 1899: 7. See also Lara Baker Whelan, Class, Culture and Suburban Anxieties in the Victorian Era (New York: Routledge, 2010).

${ }^{132}$ "The Folk-Song Society," 81.

${ }^{133}$ Low, "The Rise of the Suburbs," 553.
}

"unhealthy" cultural wastelands occupied by those enamoured of mere "musical slang."

Such rhetoric bore witness not only to undeniable social ills, but also to widespread fears of social, aesthetic, and racial decline. Demanding urgent reform in 1900, the journalist Robert Donald noted that under the clamor of reporting on the Boer War "the needless waste of life in the struggle for existence in the slums of our large cities goes on, silently and unseen": diseases spread, children "die by the thousand before they know how to suffer," and "degeneracy-moral and physical-poisons an ever-widening circle." ${ }^{134}$ "Unless the workmen's colonies in the suburbs are built under better conditions," Donald stressed, "we will be simply manufacturing more slums for the future," particularly given that health laws in such areas are "not strictly enforced" and that the Building Acts are "nearly always a dead letter." ${ }^{\prime 135}$ This sensitivity to the idea of degeneration was one of the foremost obsessions among European intellectuals at the time-exemplified by Max Nordau's Entartung, a book attempting to identify the pathological aspects of contemporary art, urbanization, and social decadence, and their baleful effects on the human body. ${ }^{136}$ An 1892 article in the National Observer entitled "Degeneracy," for instance, bemoaned the "plain," "under-sized," and "ill-made" figures

\footnotetext{
${ }^{134}$ Robert Donald, "Housing the Poor: Experiments and Problems," Contemporary Review 77 (March 1900): 323-33, 323

${ }^{135}$ Ibid., 333.

${ }^{136}$ Max Nordau, Entartung [Degeneration], ed. Karin Tebben (Berlin: De Gruyter, 2013). On the history underlying such work, see Gregory Claeys, "The 'Survival of the Fittest' and the Origins of Social Darwinism," Journal of the History of Ideas 61/2 (2000): 223-40; Mike Hawkins, Social Darwinism in European and American Thought, 1860-1945: Nature as Model and Nature as Threat (Cambridge: Cambridge University Press, 1997); Evolution and Victorian Culture, ed. Bernard Lightman and Bennett Zon (Cambridge: Cambridge University Press, 2014); and Stephen Jay Gould, The Mismeasure of Man (New York: Norton, 1996). The beginnings of musicology are entangled with such ideas. See Alexander Rehding, "The Quest for the Origins of Music in Germany Circa 1900," Journal of the American Musicological Society 53/2 (2000): 345-85; Nicholas Cook, The Schenker Project: Culture, Race, and Music Theory in Fin-de-Siècle Vienna (Oxford: Oxford University Press, 2007); and Rachel Mundy, "Evolutionary Categories and Musical Style from Adler to America," Journal of the American Musicological Society 67/3 (2014): 735-67.
} 
of London's working class, observing by contrast that their forebears "were ruddy, upright peasants" epitomizing a village life that had afforded mankind its "highest development." 137

Incorporating the criminological theories of Cesare Lombroso, such views were often inseparable from a rejection of Victorian mass entertainment and the new leisure pursuits of a burgeoning lower-middle class. ${ }^{138}$ The prison physician Isabel Foard argued in 1899, for instance, that Britain was descending into atavism due to inherited weaknesses of physique and intellect. The result, she argued, was "a mechanical mind bereft of its argumentative, imaginative, and individual powers" abetted by "the slight sketchy novel, without plot, appealing merely to the senses," "variety entertainment," and "the numberless magazines ... of a light nature, with no attempt at literary effort or style, turned out for the reading of the million." ${ }^{\prime 139}$ This debilitating culture of "rapidity" and a "growing inability to concentrate ideas," Foard noted, was also due (as Parry implied) to "the influence of alcohol."140

Parry's remedy for such malaise was the levelheaded, restorative power of folk song. Understood as an instantiation of the rural more broadly, folk song offered a means to rejuvenate the deteriorating cultural life of the nation just as influxes of rural laborers themselves might revitalize the ailing and enervated racial stock of conurbations. As Low points out, in an epoch of "urban supremacy, the greatness of the towns has been made less by townsmen than by immigrants from the country": "What will become of the feeble anæmic urban population," he inquires, "when there can be no more immigration from the villages

\footnotetext{
137"Degeneracy," National Observer, 18 June (1892): $114-15,115$

${ }^{138}$ See Peter Bailey, Leisure and Class in Victorian England: Rational Recreation and the Contest for Control, 1830-1885 (London: Routledge \& Kegan Paul, 1978) and Popular Culture and Performance in the Victorian City (Cambridge: Cambridge University Press, 1998). See also Paul Knepper, The Invention of International Crime: A Global Issue in the Making, 1881-1914 (Basingstoke: Palgrave Macmillan, 2010).

${ }^{139}$ Isabel Foard, "The Power of Heredity," Westminster Review 151/5 (1899): 538-53, 538.

${ }^{140} \mathrm{Tbid}$.
}

to repair its exhausted vitality?"141 Replenishing the imperial metropolis and delivering men "with the stalwart frames, the well-chiselled features, the straight limbs of the descendants of the Norse and Saxon tribes that settled on the soil," rural inhabitants-and, by analogy, their pastoral songs-were potential redeemers of the nation and indeed of Empire. ${ }^{142}$

One writer nevertheless spotted the paradox secreted within this project of revivalism. Folk music was believed to be the unique and hermetic expression of national identity in a Britain that had for centuries extended its colonizing dominion across the globe. Given such "overlapping territories" the country was thus the product of what Edward Said describes as "intertwined histories." ${ }^{143}$ The same year that Parry delivered his inaugural address to the Society, Baughan wrote the following under the title "A Plea for Cosmopolitanism":

It will, perhaps, seem rather far fetched to trace the influence of our genius for colonization on our music, but in these days, when our foremost composers show a decided inclination to apologize for the cosmopolitan character of British music, and to dig into the mine of Folk-song, it is necessary to point out that Great Britain is not as other nations, that her sons have carried her flag to every part of the habitable globe, and that the country itself is nothing more than a large warehouse with a thriving brokerage business attached. ${ }^{144}$

It would be absurd, Baughan continues, to suppose that such a history had no effect on national character, and "equally absurd to speak of one character" given the self-evidently hybrid nature of human descent. ${ }^{145}$ In agreement with Parry regarding the general trajectory of musical development, Baughan nevertheless proposes that the

\footnotetext{
${ }^{141}$ Low, "The Rise of the Suburbs," 553.

${ }^{142}$ Ibid. It is here that the folk-song movement betrays its deep and undeniable links to the nascent culture of European fascism. See Zeev Sternhell, Neither Right nor Left: Fascist Ideology in France, trans. David Maisel (Berkeley: University of California Press, 1986) and Sternhell, The Anti-Enlightenment Tradition, trans. David Maisel (New Haven: Yale University Press, 2010). I deal with this issue at greater length in Cole, "On the Politics of Folk Song Theory."

${ }^{143}$ Said, Culture and Imperialism, 1.

${ }^{144}$ Edward Baughan, "A Plea for Cosmopolitanism," Monthly Musical Record 28/326 (1898): 25-26, 25.

${ }^{145}$ Ibid.
} 
introduction of native song into contemporary composition is an artificial "masquerade." ${ }^{146}$ As the outpouring of "a people less fortunate and lower in the scale of human culture" containing "little of that healthier, broader, and more sublime thought that is characteristic of man when educated and civilized," folk song was out of touch with "modern complexity" and its devotees too inclined to think that "all the virtues of mankind lie in the simplicity of the untutored mind. ${ }^{147}$

What Baughan might also have pointed out was that this "genius for colonization" was manifest at the very heart of the folk-song project. It was only through colonialist discourse that folk music could be classified as the product of "primitive" minds. Indeed, the entire field was predicated on what de Certeau describes as an ethnological rectangle: orality (art practiced within "a primitive, savage, or traditional society"), spatiality (a "synchronic picture" of that society), alterity (difference arising from a "cultural break"), and unconsciousness ("the status of collective phenomena"). ${ }^{148}$ The ethnological or folkloric spectator's role is then to collate, translate, and organize this culture into notated documents. It was this ethnological nexus that allowed Parry and others to position folk song as the deepest wellspring of European musical heritage and thus as a potentially restorative force.

Echoing what Johannes Fabian pinpoints as the "allochronic" tendencies of early anthropology, the folkloric imagination was indebted to the historiographical model Parry outlined in The Evolution of the Art of Music-a book drawing on a teleological vision of development indebted to Spencerian theory. ${ }^{149}$ For Parry, music progressed "parallel to the general development of capacities of all kinds in the human race. ${ }^{\prime 150}$ As a pure, aboriginal, and autonomous outpouring of collective expres-

\footnotetext{
${ }^{146}$ Tbid.

${ }^{147}$ Ibid., 26.

${ }^{148}$ De Certeau, The Writing of History, 209.

${ }^{149}$ Johannes Fabian, Time and the Other: How Anthropology Makes Its Object (New York: Columbia University Press, 2014), 37; see also Mundy, "Evolutionary Categories."

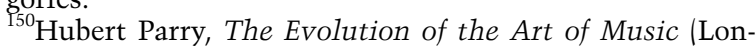
don: K. Paul, Trench, Trübner, 1896), 48.
}

sion one step beyond a "savage" phase of humanity, folk songs were "the spontaneous utterances of the musical impulse of the people" standing in direct contrast to the "vulgarised and weakened portions of the music of the leisured classes. ${ }^{\prime 151}$ Denied a voice of their own, the folk became the vicarious mouthpiece of a fearful establishment, conduits of a radical, unsullied, and hence restorative populist sensibility to counter the false and disconcerting populism of the metropolis. Utilizing a framework derived from evolutionary philosophy and the colonial enterprise, Parry was able to establish a vision of humanity containing within itself demonstrable traces of its own progression from premodern barbarism to modern civilization. Folk song relied upon this postulate to stage a dialectical return, employing traces of primitive "folk" culture as a redemptive antidote to the ills of fin-de-siècle modernity.

\section{A Geography of the Forgotten}

Written in collaboration with Dominique Julia and Jacques Revel, de Certeau's essay "The Beauty of the Dead" underscores a paradox central to the idea of popular and, by extension, folk culture. The social function of discourse on such milieux, he states, is to "conceal what it claims to show." ${ }^{152}$ Grounding his argument in the work of Charles Nisard-head of the French Ministry of Police's Commission for the Examination of Chapbooks during the 1850s-de Certeau demonstrates that what historians of the era have taken to be a culture of the people was in fact the result of systematic inventorying, censorship, and prohibition by municipal authorities. Studies of street literature were predicated on the selective expurgation of an object reserved only for enlightened specialists. Purged of immorality and potential revolutionary danger, popular material was the idealized result of political discipline and subjugation. By the time of the

\footnotetext{
${ }^{151}$ Ibid., 80.

${ }^{152}$ Michel de Certeau, "The Beauty of the Dead: Nisard," in Heterologies: Discourse on the Other, trans. Brian Massumi (Minneapolis: University of Minnesota Press, 1986), $119-36,121$.
} 
Third Republic, however, a shift had occurred in which the popular became less an alarming terrain in need of correction than the locus of a cohesive national identity. The birth of folklore "ensured the cultural assimilation of a henceforth reassuring museum. ${ }^{\prime 153}$ Nonetheless, before becoming a legitimate object of scholarly interest, popular culture had first to be filtered through the instrumentalizing gaze of certified gatekeepers.

The story of folk song in England echoes this long history of Romantic reimagination. As with France, "a political faction in search of a new alliance" employed the supposedly childlike or primitive qualities of rural folklore as a means to "put the peasant back in the worker," elevating democracy while simultaneously guarding against the latent threat of mass insurrection. ${ }^{154}$ Set up as the antidote to demographic change and escalating urban industrialization, the imagined corpus of "the folk" proved to be the perfect tabula rasa upon which the historiographical, political, and ethnological fantasies of the fin de siècle could be inscribed.

The voice of the people has most often been constituted by its repression-through selection, reclassification, regulation, dislocation, writing, and censorship. We thus return to the idea that folklore is popular culture under erasure, or in specifically musical terms: folk song = vernacular song. Folk song concealed the very thing it claimed to exemplify. Through folk song we do not hear the voice of the people, but rather popular voices modulated by a series of gatekeeping decisions. Rather than presenting the sound of a communal throng, folk song emerged from a series of highly mediated encounters with unique and often exceptional singers such as Henry Burstow and the Copper brothers. These figures became entrapped within a twofold synecdoche in which an individual singer or song was made to stand for "the folk" as a whole, and "the folk" in turn were made to stand for the idealized political community of the nation. We must, de Certeau asserts, be

\footnotetext{
${ }^{153}$ Ibid., 124.

${ }^{154}$ Ibid., 124-25.
}

ready to give up the yearning to collect these disparate intonations and expressions "under the sign of a 'Voice,' or of a 'Culture' of its own-or of the great Other's." ${ }^{\prime 155}$ To put it in de Certeau's terminology, late Victorian folkloric praxis functioned as a strategy-a panoptic operation transforming "the uncertainties of history into readable spaces" by filling the undocumented lacunae of everyday life with ideological speculation. ${ }^{156}$ In this scheme, the folk appeared as native noble savages, caught in a camouflaged violence that oscillated "between voyeurism and pedagogy" and pointed toward "the reservation and the museum. ${ }^{\prime 157}$ Predicated upon a quixotic pursuit of lost origins, de Certeau reminds us, the vocabulary of folklore defines "less the content of a popular culture than the historian's gaze itself." 158

The relations and regularities established between institutions, material culture, enunciations, and concepts within the folkloric imagination form the basis of what Michel Foucault characterizes as a "discursive formation." ${ }^{159}$ In order to establish credibility, de Certeau proposes, "Discourse binds itself to the institutional structure that legitimates it in the eyes of the public" - in this case, to organizations such as the Folk-Song Society. ${ }^{160}$ Although the folk never existed, they were brought into being through discourse itself. Folk song and the folk were conjured up via the discursive strategies that claimed merely to describe them. Folk song devotees nevertheless saw themselves as redeemers of an art on the brink of a descent into obscurity and ruin. Their vision of folk song became a fulcrum between the commercial ruckus of broadside culture and the establishment of an anti-commercial pastoralism that longed to

\footnotetext{
${ }^{155}$ De Certeau, The Practice of Everyday Life, 132.

${ }^{156}$ Ibid., 36.

${ }^{157}$ De Certeau, "The Beauty of the Dead," 125. See also Ter Ellingson, The Myth of the Noble Savage (Berkeley: University of California Press, 2001).

${ }^{158}$ De Certeau, "The Beauty of the Dead," 129.

${ }^{159}$ Michel Foucault, The Archaeology of Knowledge, trans. A. M. Sheridan Smith (London: Routledge, 2002), 130

${ }^{160}$ Michel de Certeau, "History: Science and Fiction," in Heterologies, 199-21, 207.
} 
enfold the unselfconscious primitivism of these once prodigal low Others into the national culture as a remedy for the encroachments of modernity, technological progress, and the inexorable flow of capital. Intended as an instrument of social metamorphosis, folk song became an institutionally endorsed means of animating "the folk" from the purified and reforged residues of vernacular culture-a domain that first needed to be notated, categorized, and sanitized in order to count as folklore. Collectors at the fin de siècle acted as the channels through which this "folk" culture had to pass in order to be understood as such. The resultant folk were required only ever to be artisanal producers or bearers of an endangered tradition, never alienated consumers of commercial entertainment. Theirs was the very opposite of a new identity developing within urban mass society.

We should not forget that strong voices of dissent have always accompanied the folkloric imagination. In a polemical 1921 monograph entitled Poetic Origins and the Ballad, for example, the brilliant but overlooked American scholar Louise Pound proclaimed that the notion of the spontaneous oral generation of songs by a folk community was a "fatuously speculative" hypothesis that had thrown the entire field of literary studies out of kilter. ${ }^{161}$ The fact "that songs have been preserved in remote districts and among the humble," she stresses, "is no proof that they were composed in such places and by such people"; rather, this material was "literature 'for' not 'by' the people.."162 Given that many collectors had focused their "salvage" on the Child ballads, she notes, they were liable to ignore "many related types of song of equal or greater currency" among the population. ${ }^{163}$

\footnotetext{
${ }^{161}$ Louise Pound, Poetic Origins and the Ballad (New York: Macmillan, 1921), 35, 34. For biographical information, see Robert Cochran, Louise Pound: Scholar, Athlete, Feminist Pioneer (Lincoln: University of Nebraska Press, 20091.

${ }^{162}$ Pound, Poetic Origins, 91, 106. This last phrase is a deliberate inversion of a theory expounded by Francis Barton Gummere in Old English Ballads (Boston: Ginn \& Company, 1894).

${ }^{163}$ Pound, Poetic Origins, 120.
}

Pound summed up this revisionist argument in an article for PMLA, charting how the history of Romantic efforts to conceive of humanity en masse had led toward "the bizarre belief in a collective soul which is not to be found in the nature of the souls of the individuals which compose the social group, but which in some mystic sense enwraps the individuals in its all-obscuring fog." 164 "If history and indeed ethnology betray clearly one fact," she affirms, "it is that there is no such 'mental homogeneity' among men. . . . Conscious effort, cool judgment, and creative intelligence are gifts of men, not of mobs. ${ }^{\prime 165}$ Pound was at pains to accentuate that scholars must resist the temptation of forcing Others to speak through gestures of cultural ventriloquism: "Where the primitivist seeks to replace human thought by dancing puppets, the critic of the tradition endeavors to single out, from the midst of puppetdom, creative human intelligences."166

The institutionalization of folk song as an object of intrigue at the fin de siècle exhibits precisely the failing that Pound diagnosed-a cultural dramaturgy in which the intricacies of vernacular singing are replaced by shadow play. Pound was not content merely to deconstruct such representations, however, but also advocated searching out moments of "creative intelligence" or what de Certeau would later refer to as tactics. In contrast to strategies of control, tactics are covert and guileful acts of resistance, often depending on linguistic dexterity and wit that develop from positions of weakness. ${ }^{167}$ Dissatisfied with views of society founded upon hegemonic power, passivity, and domination, de Certeau employed this concept as a way to theorize quotidian patterns of consumption, use, and movement as acts of subaltern agency that breach or trespass across the disciplinary structures that Foucault identified. This perspective offers a way to rethink the history of vernacular song by resisting romanticized

\footnotetext{
${ }^{164}$ Louise Pound, "The Term 'Communal'," PMLA 39/2 (1924): 440-54, 444.

${ }^{165}$ Ibid., 444-46.

${ }^{166}$ Ibid., 445-46.

${ }^{167}$ De Certeau, The Practice of Everyday Life, 37.
} 
or anachronistic views of laboring people and transforming "what was represented as a matrix-force of history into a mobile infinity of tactics. ${ }^{\prime 168}$ In so doing, we might rescue the marginalized histories of vernacular singing from the strategic operations of folk song. As Mary Brown writes, echoing Pound, by reconfiguring and detaching this field of inquiry "from the fanciful and intriguing imagined past" we might resuscitate popular singing "as a fluid, dynamic practice more nearly reflecting its lived reality. ${ }^{\prime 169}$ This lived reality is what folk song has repeatedly silenced. Searching out, illuminating, and recuperating these blank spots and murmurings-what de Certeau describes as a "geography of the forgotten"-is what the study of vernacular song now demands.

\footnotetext{
${ }^{168}$ Ibid., 41.

${ }^{169}$ Mary Ellen Brown, "Placed, Replaced, or Misplaced? The Ballads' Progress," Eighteenth Century: Theory and Interpretation 47/2 (2006): 115-29, 123.
}

Abstract.

This article foregrounds discrepancies between vernacular singing in England and the work of London's Folk-Song Society during the 1890s. Figures such as Lucy Broadwood, Kate Lee, and Hubert Parry acted as gatekeepers through whom folk culture had to pass in order to be understood as such. Informed by colonialist epistemology, socialist radicalism, and literary Romanticism, what may be termed the "folkloric imagination" concealed the very thing it claimed to identify. Folk song, thus produced, represents the popular voice under erasure. Situated as the antidote to degeneration, burgeoning mass consumer culture, and escalating urbanization, the folk proved to be the perfect tabula rasa upon which the historiographical, political, and ethnological fantasies of the fin de siècle could be inscribed. Positioned as a restorative bulwark against the shifting tides of modernity, the talismanic folk and their songs were temporal anachronisms conjured up via the discursive strategies that attempted to describe them. Increased attention should hence be paid to singers such as Henry Burstow and the Copper brothers of Rottingdean in order to rescue their histories from the conceptual apparatus of folk song.

Keywords: Folk-Song Society, fin de siècle, Britain, popular culture, colonialism 